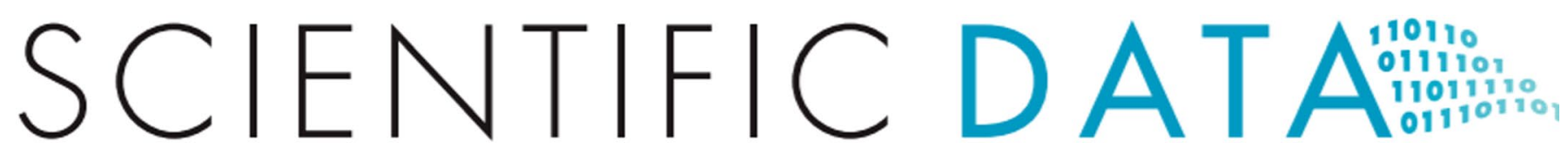

Published online: 16 March 2021

\title{
Publisher Correction: Author Correction: A patient-centric dataset of images and metadata for identifying melanomas using clinical context
}

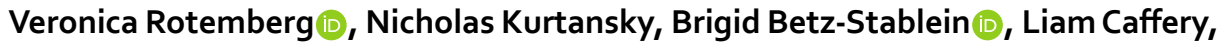
Emmanouil Chousakos (iD, Noel Codella, Marc Combalia, Stephen Dusza, Pascale Guitera,

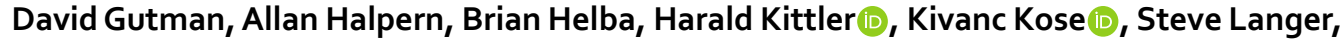
Konstantinos Lioprys, Josep Malvehy, Shenara Musthaq, Jabpani Nanda, Ofer Reiter, George Shih, Alexander Stratigos, Philipp Tschandl (D, Jochen Weber \& H. Peter Soyer (iD

Correction to: Scientific Data https://doi.org/10.1038/s41597-021-00865-3, published online 05 March 2021

In the corrected version of this Data Descriptor, an error was introduced in the spelling of H. Peter Soyer which was incorrectly given as H. Peter Seter. This has now been corrected in both the PDF and HTML versions of the Data Descriptor.

(i) Open Access This article is licensed under a Creative Commons Attribution 4.0 International License, which permits use, sharing, adaptation, distribution and reproduction in any medium or format, as long as you give appropriate credit to the original author(s) and the source, provide a link to the Creative Commons license, and indicate if changes were made. The images or other third party material in this article are included in the article's Creative Commons license, unless indicated otherwise in a credit line to the material. If material is not included in the article's Creative Commons license and your intended use is not permitted by statutory regulation or exceeds the permitted use, you will need to obtain permission directly from the copyright holder. To view a copy of this license, visit http://creativecommons.org/licenses/by/4.0/.

(C) The Author(s) 2021 